\title{
O PRINCÍPIO DA LEGALIDADE E OS LIMITES DO PODER REGULAMENTAR
}

\section{THE PRINCIPLE OF LEGALITY AND THE LIMITS OF REGULATION POWER}

\section{RESUMO:}

O presente artigo procura analisar o poder regulamentar sob o ponto de vista do princípio da legalidade e da compreensão que se deva ter de legalidade e de juridicidade a partir de uma visão mais consentânea com a realidade bem como a partir de decisões do próprio Supremo Tribunal Federal, adotando-se um posicionamento que vislumbra, ao lado das reservas absolutas de lei previstas no texto constitucional, uma reserva legal relativa, menos rígida.

PALAVRAS-CHAVE: Princípio da legalidade - Poder regulamentar - Reserva de densificação mínima.

\begin{abstract}
:
This article analyzes the regulation power from the point of view of the principle of legality and the understanding of the concepts such as juridicity and legality from a more modern perspective and also acccording to decisions of the Supreme Federal Court, Adopting a position that consideres, alongside the absolute reserve of statute as written in many articles in the Federal Constitution, a relative, less rigid legal reserve.
\end{abstract}

KEYWORDS: Principle of legality - Regulation power - Minimum normative densification.

\footnotetext{
${ }^{1}$ Procurador do Município do Recife. Mestrando em Direito Administrativo pela UFPE.

${ }^{2}$ Doutor em Direito pela UFPE. Professor da Faculdade de Direito do Recife/UFPE.
} 


\section{INTRODUÇÃO}

O poder regulamentar é um daqueles temas clássicos do direito administrativo, recorrentemente tratado pela literatura especializada e sujeito, ainda hoje, a muitas dúvidas e controvérsias. Isso pode ser parcialmente explicado pela estreita vinculação desse tema com o princípio da legalidade, que tem experimentado relevantes transformações, e, também, em razão da própria mutação da concepção de Estado que se tem presente, considerando a natureza e a extensão de suas atribuições que vêm se modificando sensivelmente desde a implantação dos ideais revolucionários da França do século XVIII até os dias atuais.

Com efeito, a concepção hodierna de legalidade superou a noção da lei formal, ampliando o rol das fontes do Direito Administrativo, englobando, destarte, não apenas a lei aprovada pelo Parlamento, mas todo o Direito, ou seja, o sistema jurídico em sua integralidade (NOBRE JR, 2009, p. 215).

Fala-se, hoje, num princípio da juridicidade para expressar a ampliação da noção de legalidade, fenômeno este, de certo modo, antevisto pela noção de "bloco de legalidade” de Maurice Hauriou (1900, p. 30), a partir da experiência francesa ${ }^{3}$.

Prosper Weil (1977, p. 117), após afirmar que a concepção originária de legalidade, antes de representar uma vinculação da Administração ao Direito (Estado de Direito), significava uma vinculação ao parlamento, único órgão estatal apto a exprimir a "vontade geral", pondera que "Com o uso, o termo legalidade recebeu, contudo, um significado mais lato e tornou-se sinônimo de regularidade jurídica, de juridicidade: o 'bloco da legalidade' (HAURIOU) compreende hoje o conjunto de regras jurídicas que limitam a atividade administrativa".

No âmbito do direito administrativo brasileiro, Rafael Carvalho Rezende Oliveira (2011, p. 64) reconhece que "o princípio da legalidade encontra-se atualmente contido

\footnotetext{
${ }^{3}$ Hauriou (1900, p. 30), trata da questão no tópico "II. De la soumission au 'bloc légal' de toutes les existences sociales y compris l'Etat lui-même", ou seja, numa tradução livre, "a submissão ao bloco legal de toda a vida social, incluindo o próprio Estado".
} 
em um princípio mais amplo, que traduz com maior fidelidade a ideia de constitucionalização do ordenamento jurídico: o denominado 'princípio da juridicidade "’”.

Por sua vez, Adolf Merkl, ainda na primeira metade do século passado, formulou a noção de juridicidade em bases distintas da noção de ampliação do "bloco de legalidade". Com efeito, segundo Merkl (2014, p. 224), o princípio da juridicidade representa um postulado jurídico-teórico que se funda na própria natureza de função jurídica inerente a todas as atividades do Estado (não apenas à atividade administrativa). Seria, portanto, a "conexão necessária entre direito e administração" e se revelaria na medida em que toda ação administrativa concreta, para assim ser considerada, deve ser analisada do ponto de vista de sua relação com a ordem jurídica (MERKL, 2014, p. 221). Nesse sentido, bastaria a existência de um único preceito jurídico, seja de qualquer forma, para que se tenha por satisfeito tal princípio.

Já o princípio da legalidade administrativa representaria uma forma qualificada de juridicidade, um caso especial de aplicação do princípio da juridicidade, na medida em que a lei não seria senão apenas uma dentre as fontes jurídicas. Trata-se, assim, de um "postulado jurídico-político, que demanda ser consagrado legalmente para que tenha existência jurídico-positiva" (MERKL, 2014, p. 224).

Nesse particular, Merkl (2014, p. 232) não parece divergir da noção então corrente de legalidade, vinculando-a à lei formal (e não ao ordenamento jurídico como um todo), afirmando, destarte, que o "sentido jurídico do princípio da legalidade consiste em que cada uma das ações administrativas seja condicionada por uma lei formal, do que deve resultar a licitude ou a necessidade jurídica das ações administrativas em questão".

Em suma, para Merkl (2014, p. 224), o princípio da juridicidade e o princípio da legalidade, a despeito de não estarem em oposição, "se diferenciam em diversos pontos". E essa é uma ponderação que merece uma maior reflexão, especialmente no que concerne não só à atividade administrativa normativa (que mais de perto nos interessa neste momento), mas também à praticamente todas as atividades administrativas, sejam elas concretas, negociais, procedimentais ou materiais (atos administrativos, negócios jurídicos da Administração, processos e procedimentos administrativos e atos materiais, respectivamente). 
Não nos parece adequado considerar que o princípio da juridicidade tenha $o$ condão de, tout court, substituir o princípio da legalidade ${ }^{4}$. Nem mesmo parece correto considerar que a relação existente entre juridicidade e legalidade seja a de mera continência, pelo simples fato de a juridicidade abarcar "todo o Direito" (i. e., todas as fontes jurídicas) e a legalidade compreender apenas a lei formal (ou seja, a fonte legislativa, fruto do Parlamento). Trata-se, isto sim, de níveis de análise distintos, muito embora, reconheça-se, inter-relacionados.

A afirmação de que a juridicidade substituiria a noção de legalidade teria o efeito negativo de supor que a aquela primeira vincularia a Administração do mesmo modo que esta última, ou o que é pior, que a própria noção de legalidade restaria superada na prática, o que, em verdade, não ocorre. Bastaria pensar, por exemplo, na diferença entre a vinculação da administração a um princípio constitucional (sujeita, portanto, à ponderação), de um lado, e a vinculação a uma regra legal (sujeita, pois, à subsunção).

Talvez por isso seja preferível reconhecer, como o fez Merkl em sua concepção original, que estaríamos diante de dois princípios distintos, embora relacionados, e que operam conjuntamente, muito embora em níveis diferentes de análise e de aplicação ${ }^{5}$.

Não se pense, porém, que estamos a retirar a importância do princípio da juridicidade. Ao contrário. É na juridicidade, por exemplo, que reside a análise da constitucionalidade da atuação administrativa, e, pois, de sua legitimidade mesma. E ninguém duvida que a Administração Pública deva se pautar não só pelo critério de mera legalidade, mas também pela conformidade com a Constituição e, de um modo geral, com o Direito ${ }^{6}$.

\footnotetext{
${ }^{4}$ Nesse sentido, Raimundo Parente de Albuquerque Júnior (2010, p. 205-206).

${ }^{5}$ Não se está aqui a reproduzir a teorização da MERKL na íntegra, como se pudéssemos, simplesmente transpor para o Direito pátrio as noções estabelecidas pelo jurista austríaco. Pretende-se tão-somente deixar assentado que, tal como reconhecia MERKL, o princípio da juridicidade não se confunde, não substitui o princípio da legalidade. São dois princípios distintos, duas metodologias de análise e de aplicação, sem deixar de reconhecer que se tratam, efetivamente, de princípios correlacionados. É imperioso destacar, porém, que a ideia aqui defendida merece maiores desdobramentos que não são possíveis neste momento, em razão da propositada limitação temática do presente trabalho.

${ }^{6}$ Daí a expressão constante do art. 20.3 da Constituição alemã que diz assim: "os poderes executivo e judiciário obedecem à lei e ao direito". Tal distinção foi reproduzida, entre nós, em caráter muito mais restrito, pelo art. $2^{\circ}$, parágrafo único, inciso I, da Lei 9.784/99, ao se referir a "atuação conforme a lei e o Direito" no âmbito do processo administrativo federal.
} 
Todavia, não é menos verdade que o princípio da legalidade, no sentido da vinculação à lei formal, a despeito de todas as “crises" pelas quais esta última possa estar sujeita, pelo menos do ponto de vista do Direito positivo brasileiro, ainda é o principal instrumento de delimitação da atividade administrativa, revelando, ainda, um nítido cunho garantístico que deve ser preservado.

O que se pretende aqui deixar assentado, portanto, é que o princípio da legalidade, no sentido da vinculação da Administração à lei formal, ainda é noção indispensável para a compreensão dos institutos do direito administrativo, dentre os quais, o poder regulamentar de que estamos a tratar neste momento.

\section{O PODER REGULAMENTAR NO QUADRO DA COMPETÊNCIA NORMATIVA DA ADMINISTRAÇÃO}

Conforme Marcello Caetano (2015, p. 95), o regulamento administrativo (fruto do exercício do poder regulamentar) seria uma "norma jurídica de caráter geral e execução permanente dimanada de uma autoridade administrativa sobre matéria própria da sua competência”. Essa noção traduz uma ideia mais geral de poder regulamentar calcada na competência normativa atribuída à Administração Pública.

No mesmo sentido, Maria Sylvia Zanella Di Pietro (2014, p. 91) afirma que o poder regulamentar não esgota toda a competência normativa da Administração, constituindo apenas uma de suas formas de expressão. De igual modo, Odete Medauar (2012, p. 127) deixa claro que o poder regulamentar não é outra coisa senão um dos modos de exercício do chamado poder normativo atribuído à Administração Pública. Ambas as autoras reconhecem, pois, que o poder regulamentar constitui uma das formas específicas de exercício do poder normativo da Administração atribuída ao Chefe do Poder Executivo, a fim de editar normas complementares à lei para a sua fiel execução.

Questiona-se se o chamado poder regulamentar seria apenas aquele atribuído ao Chefe do Poder Executivo, por força do art. 84, IV, da Constituição Federal, com entende, por exemplo, Cretella Jr (1995, p. 269), ou, ao contrário, poderia ser atribuído, a partir de previsão constitucional ou legal, expressa ou implícita, a outra autoridade, órgão ou ente. 
Nesse particular, concordamos com Marcílio da Silva Ferreira Filho (2016, p. 166) ao afirmar que essa segunda posição, reveladora de uma visão ampliativa do poder regulamentar, seria a que melhor se adequa à realidade e às necessidades no cumprimento da função administrativa. Evidentemente, o exercício do poder regulamentar por sujeito diverso do Chefe do Poder Executivo deverá, igualmente, observar os limites do poder regulamentar, não se tratando, pois, de uma "delegação legislativa sem parâmetros, mas da competência normativa regulamentar no setor específico de atuação e nos mesmos moldes do poder regulamentar típico da Administração Pública, ou seja, com status inferior à lei” (FERREIRA FILHO, 2016, p. 167).

Do ponto de vista do direito positivo, a existência dessa competência normativa da Administração está consagrada não só pelo inciso IV do art. 84, da Constituição Federal, quanto ao Chefe do Poder Executivo, mas também pelo disposto no inciso II do parágrafo único do art. 87, da nossa Lei Maior, e, de certo modo, no âmbito da regulação econômica, pelo previsto no art. 174, caput, $\mathrm{CF}^{7}$.

Ademais, utilizaremos expressão "poder regulamentar", para designar essa competência normativa específica, salientando, desde já, com base em Celso Antônio Bandeira de Mello (2004, p. 133), que os poderes atribuídos à Administração são instrumentais, representando, antes, um dever atribuído ao administrador público a fim de perseguir as finalidades públicas. Como afirma o citado autor, "o poder, na competência, é a vicissitude de um dever".

Pois bem. O tema do poder regulamentar não pode ser adequadamente perscrutado sem adentrarmos na análise do princípio da legalidade e da relação que se estabelece entre a lei e o regulamento, ou seja, entre os provimentos típicos dos Poderes Legislativo e Executivo $^{8}$, respectivamente.

\footnotetext{
${ }^{7}$ No tocante às agências reguladoras, esse poder normativo teria como base constitucional, além das

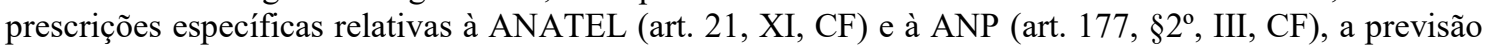
genérica do art. 174, caput, $\mathrm{CF}$, que, em tese, albergaria a atribuição dessa competência para outras agências criadas por lei, sem previsão constitucional expressa.

${ }^{8}$ Evidentemente, não se está a desconsiderar que o Judiciário e o Legislativo exerçam atividade administrativa e, em alguns casos, detenham da competência regulamentar. Não se trata, porém, da atividade típica desses dois Poderes, restando ao Poder Executivo a preponderância no exercício dessa atividade administrativa.
} 
Por outro lado, o princípio da legalidade deve ser compreendido a partir do arcabouço constitucional de cada ordenamento jurídico, não se podendo, de antemão, assumir como válidas perante a ordem jurídica brasileira determinadas conclusões produzidas no âmbito de outros sistemas constitucionais, ainda que pertencentes a um sistema jurídico de origem comum, de base romanística ${ }^{9}$.

Do ponto de vista formal, parece ser consenso que o regulamento possui hierarquia normativa inferior à lei. Em razão disso, e invocando os preceitos do art. $5^{\circ}$, II e do art. 84, IV, ambos da Constituição Federal, parte da doutrina administrativista ${ }^{10}$ procura resolver a questão da relação entre a lei e o regulamento de modo bastante simplista, afirmando que os regulamentos devem ser expedidos apenas para fiel execução da lei, não podendo ser emitido contra legem ou ultra legem (DI PIETRO, 2014, p. 92), e que, no direito brasileiro só existem regulamentos executivos, que não poderiam inovar em caráter inicial na ordem jurídica (BANDEIRA DE MELLO, 2004, p. 312-313).

Nesse sentido, a Administração seria mera executora de decisões tomadas de modo completo pelo legislador, restando-lhe pouco ou nada a acrescentar, na medida em que a inovação por regulamento lhe é vedada.

Esse posicionamento parece-nos, se não inteiramente equivocado, ao menos insuficiente. Seja porque nem o art. $5^{\circ}$, II, CF traduz o princípio da legalidade em sua completude, nem o poder regulamentar se encerra na dicção do inciso IV, art. 84, CF; seja por não levar em conta as modificações sociais e técnicas que vêm produzindo uma sociedade cada vez mais plural e complexa, insuscetível de ser normatizada de forma ampla e exclusiva pela lei formal aprovada pelo Parlamento.

\footnotetext{
${ }^{9}$ Isso se verifica, por exemplo, com relação ao direito francês, que permite sejam determinadas matérias tratadas diretamente pelo regulamento (conforme artigo $37^{\circ}$ da Constituição de 1958, que assim reza "Assuntos diferentes dos que estão no âmbito da lei têm um caráter regulamentar"), ou com relação ao direito alemão, que permite a delegação de competências legais para o regulamento (artigo 80.1 da Lei Fundamental de Bonn, de 1949, ao prever que "Através de lei, podem ser autorizados a promulgar decretos o Governo Federal, um Ministro Federal ou os governos estaduais. Para tal, a lei deve determinar conteúdo, objetivo e extensão da autorização outorgada. O decreto deverá conter o dispositivo legal que o fundamenta. Quando a lei prevê que uma autorização pode ser subdelegada, a subdelegação da autorização deverá ser efetuada por um decreto"). Ambos os casos inocorrem no direito brasileiro, razão pela qual as conclusões dos autores franceses e alemães (ou de qualquer outro sistema jurídico estrangeiro), para fundamentar qualquer posicionamento perante o ordenamento jurídico brasileiro, devem ser vistas com extrema cautela.

${ }^{10}$ E a título exemplificativo, podemos citar BANDEIRA DE MELLO (2004, p. 312-318) e DI PIETRO (2014, p. 91-95).
} 
A título exemplificativo, podemos citar a decisão do STF no julgamento do RE 343.446/SC (BRASIL, 2003), relatado pelo Ministro Carlos Velloso, a respeito da constitucionalidade da contribuição para o custeio do Seguro de Acidente do Trabalho SAT. Dentre outras questões ventiladas no acórdão, o Plenário do STF, naquela ocasião, assentou que, tendo a lei definido satisfatoriamente todos os elementos capazes de fazer nascer a obrigação tributária válida, a circunstância dessa mesma lei ter deixado para o regulamento a complementação dos conceitos de "atividade preponderante" e de "grau de risco leve, médio e grave" não implicaria em ofensa ao princípio da legalidade genérica prevista no inciso II do art. $5^{\circ}, \mathrm{CF}$ e da legalidade tributária, conforme o art. 150, inciso I, CF.

Com efeito, conforme afirma o Min. Carlos Velloso (BRASIL, 2003, p. 14041405), em seu voto:

Em certos casos, entretanto, a aplicação da lei, no caso concreto, exige a aferição de dados e elementos. Nesses casos, a lei, fixando parâmetros e padrões, comete ao regulamento essa aferição. Não há falar, em casos assim, em delegação pura, que é ofensiva ao princípio da legalidade genérica (C.F., art. $5^{\circ}$, II) e da legalidade tributária (C.F., art. 150, I) ${ }^{11}$.

Há, ainda, outro aspecto que a doutrina mais tradicional, não leva em consideração: a vinculação da Administração à lei se dá em diversos graus, a depender principalmente da (i) disciplina constitucional específica (entenda-se, da conformação constitucional do princípio da legalidade) e (ii) do nível de densidade normativa da lei oferece de tal sorte a permitir uma maior ou menor amplidão do exercício do poder regulamentar.

\section{DOS GRAUS DE VINCULAÇÃO DA ADMINISTRAÇÃO À LEI - A CONFORMAÇÃO CONSTITUCIONAL DO PRINCÍPIO DA LEGALIDADE}

\footnotetext{
${ }^{11}$ Faz-se, então, uma distinção entre a delegação pura e simples (que, de fato, seria ofensiva ao princípio da legalidade) da "atribuição que a lei comete ao regulamento para aferição de dados, em concreto, justamente para a boa aplicação concreta da lei”.
} 
Dito de uma maneira bastante simplista, o princípio da legalidade vincula a Administração às prescrições legais, o que, consoante Odete Medauar (2009, p. 136), pode ser traduzido pela fórmula segundo a qual "a Administração deve sujeitar-se às normas legais". Não obstante a aparente simplicidade dessa formulação, questões relevantes quanto ao modo de sua aplicação, ou melhor, o modo pelo qual a Administração se vincula e deva obedecer a tal princípio, devem ser consideradas. Dito por outros termos, o modo ou grau com que se dá essa vinculação varia consideravelmente, a depender do arcabouço constitucional do princípio e da própria densidade normativa da lei.

Tanto é que Alexandre Santos de Aragão (2004, p. 51) afirma haver pouca divergência quanto à exigência de base legal para a atuação da Administração, concentrando-se os debates "no nível de densidade normativa das quais estas leis devem se revestir para outorgar poderes à Administração; ou seja, até que ponto a lei deve preestabelecer os conteúdos dos atos a serem expedidos infra-legalmente pela Administração".

Charles Eisenmann $(1959, \text { p. } 54)^{12}$ vislumbra quatro modos distintos pelos quais a Administração se vincula à lei. Segundo ele haveria (i) uma noção mínima, segundo a qual a legalidade seria uma "relação de não-contrariedade, de não-incompatibilidade, ou, positivamente, de compatibilidade”, o que significa dizer que a Administração, na ausência de lei que lhe impusesse determinada conduta, positiva ou negativa, teria ela um amplo grau de liberdade. Ou conforme suas palavras: “o 'princípio de compatibilidade' permitirá à Administração fazer tudo o que não lhe seja, de uma forma ou de outra, interdito pela lei” (1959, p. 56).

Por seu turno, existiria uma noção máxima, que vê na legalidade uma "relação de conformidade", ou seja, a Administração somente poderia atuar de forma totalmente vinculada a lei, sem qualquer margem de liberdade para definir conteúdos de atos normativos ou concretos. Como afirma Eisenmann (1959, p. 56), “o princípio da

\footnotetext{
${ }^{12}$ Convém destacar que o artigo de EISENMANN aqui referido, foi traduzido da publicação francesa de 1957 da Études et Documents - Conseil d'État (EDCE), Paris, fasc. 11, consoante nota constante ao final do texto em português. Ou seja, fora escrito ainda sob a égide da Constituição Francesa de 1946, que não tratou de forma expressa sobre o âmbito de competência do poder regulamentar, como o fez a Constituição de 1958 , em seu artigo $37^{\circ}$.
} 
conformidade' não lhe permitirá fazer o que não lhe for permitido, de uma forma ou e outra, por esta mesma lei”; ou ainda: “o princípio de conformidade postula a existência da regulamentação-modelo como condição necessária para cada ato".

Entre essas duas noções extremas de vinculação da Administração à lei, Eisenmann (1959, p. 63) admite duas posições intermediárias: (iii) a legalidade contemplaria tão-somente uma habilitação legal, de tal sorte que, uma vez existente uma lei que confira determinada competência (e só na medida em que houver uma tal norma habilitadora, o que já configura uma restrição ao princípio de compatibilidade posto que, nesse caso, a Administração não seria livre para agir, muito embora, uma vez autorizada por lei a agir poderia ela própria determinar o conteúdo do ato, respeitando-se, porém, os fins para os quais aquela competência lhe fora deferida); e, por fim, (iv) a legalidade demandaria não apenas a existência de uma habilitação legal (atribuição de competência), mas também a predeterminação do conteúdo do ato a ser praticado, sem que isso implique naquela noção extrema de legalidade, de determinação exaustiva e completa do conteúdo, sem qualquer margem de liberdade para a Administração.

As lições de Eisenmann foram recepcionadas no Brasil especialmente por Odete Medauar e, posteriormente, por Alexandre Santos de Aragão. Evidentemente, as suas conclusões giram em torno do direito francês ${ }^{13}$, não podendo, precisamente por isso, serem imediata e irrefletidamente incorporadas ao nosso sistema.

Não obstante, e nesse ponto parece ser a opinião de Medauar e de Aragão, suas observações têm o mérito de demonstrar que o princípio da legalidade (e aqui, como o faz Eisenmann, estamos a tratar da legalidade no seu sentido mais clássico, mais estrito, de legalidade formal) não pode ser compreendido apenas pela ideia simplista de vinculação da administração à lei, sem se levar em conta em que medida essa vinculação ocorre.

\footnotetext{
${ }^{13}$ E o direito francês sob a égide da Constituição anterior, de 1946, e não sob a vigência da atual Carta de 1958, que, como já se falou aqui, ao contrário do texto constitucional anterior, possui disciplina expressa a respeito da separação do âmbito de competência própria da lei e regulamento, tal qual se pode verificar do disposto do seu artigo $37^{\circ}$.
} 
Cabe-nos, porém, concordar com Aragão ao constatar que as concepções extremas formuladas por Eisenmann são "inviáveis" e não encontram guarida no direito administrativo brasileiro.

Com efeito, segundo Aragão (2004, p. 52), a noção de legalidade como princípio de compatibilidade colocaria em pé de igualdade as esferas de liberdade do indivíduo e da Administração, colocando em xeque a própria noção de Estado de Direito e a consequente garantia individual de proteção contra o abuso de poder do Estado.

Por sua vez, a noção de legalidade como relação de conformidade absoluta seria inviável pela razão oposta "já que impediria qualquer esfera de apreciação própria da Administração Pública em um Estado social de Direito, que possui múltiplas e complexas atribuições, a serem exercida em um contexto de grande dinamismo" (ARAGÃO, 2004, p. 52).

Para Medauar (2012, p. 136), a ideia de que somente seriam permitidos aqueles atos cujo conteúdo estivesse conforme a uma hipótese abstrata posta de modo claro por uma lei formal traduziria uma concepção rígida do princípio da legalidade e reduziria a função administrativa à mera executora da lei. Para a autora, essa concepção não pode prevalecer na atualidade. Por isso, defende ela a posição proposta por Eisenmann de legalidade enquanto habilitação legal, conforme acima referida no item (iii), afirmando o seguinte:

Esta é a fórmula mais consentânea com a maior parte das atividades da Administração brasileira, prevalecendo de modo geral. No entanto, o significado contém gradações: a habilitação legal, por vezes, é somente norma de competência, isto é, norma que atribui poderes para adotar determinadas medidas, ficando a autoridade com certa margem de escolha no tocante à substância da medida; por vezes, a base legal expressa um vínculo estrito do conteúdo do ato ao conteúdo da norma ou às hipóteses aí arroladas (MEDAUAR, 2012, p. 137).

O que fica evidente, aqui, portanto, é que a norma legislativa pode apresentar graus distintos de densidade normativa. Por conseguinte, haverá graus diversos de vinculação da Administração à legalidade o que, em última análise, se refletirá no maior ou menor grau de liberdade que a lei lhe confere para exercitar sua competência normativa. Saliente-se, porém, que essa liberdade, por mais ampla que seja do ponto de 
vista legal, estará sempre condicionada, em maior ou menor medida, ao ordenamento jurídico como um todo ${ }^{14}$, ou por outros termos, ao princípio da juridicidade.

Outra análise do princípio da legalidade admite a existência de dois componentes que lhe conferem a estrutura conceitual, como o faz Hartmut Maurer (2006, p. 121), separando, de um lado, a noção de primazia da lei; e, de outro, a de reserva de lei.

Para Maurer (2006, p. 121), o princípio da primazia da lei expressa a "vinculação da administração às leis existentes e indica que os funcionários administrativos positivamente - devem atuar em conformidade com as leis e - negativamente - não devem tomar medidas que infringem as leis". Tal princípio, segundo ele, tem validade ilimitada e incondicional para a Administração, conforme prevê o art. 20.3, da Constituição alemã.

Por seu turno, afirma ele que, pelo princípio da reserva legal, "a administração somente se pode tornar ativa se ela foi, para isso, autorizada em lei" (MAURER, 2006, p. 122). E continua:

\begin{abstract}
Esse princípio, portanto, pede mais que o princípio da primazia. Enquanto este apenas (negativamente) proíbe a infração contra leis existentes, aquele pede (positivamente) um fundamento legal para atividade administrativa. A falta de uma lei exclui um tornar-se ativo da administração não segundo o princípio da primazia, mas segundo o princípio da reserva (MAURER, 2006, p. 122).
\end{abstract}

O próprio Maurer (2006, p. 123) já deixou claro que o disposto no art. 20.3 da Constituição alemã não consagra o princípio da reserva da lei, mas sim o princípio da primazia. Além disso, consignou que "o princípio da primazia vale indiscutivelmente para todo o âmbito da administração (as autoridades nunca devem infringir leis)", deixando evidente, por sua vez, que "o âmbito de validade da reserva da lei é duvidoso e debatido" (2006, p. 125).

As noções de primazia da lei e de reserva de lei de Maurer parecem guardar certa correspondência com o que Eisenmann, respectivamente, denominou de princípio de compatibilidade e de princípio de conformidade, enquanto concepções ou derivações do princípio da legalidade. Contudo, e por óbvio, as consequências que cada um desses

\footnotetext{
${ }^{14}$ Nesse sentido, Alexandre Santos de Aragão (2004, p. 55), citando lição de Sérvulo Correia.
} 
autores atribuem a tais conceitos correspondentes não são totalmente idênticas, mas sim variáveis de conformidade com o Direito positivo de seus respectivos países.

De todo modo, a partir de tais noções, cabe-nos indagar, portanto, acerca da configuração do princípio da legalidade no Direito positivo brasileiro para, a partir daí, adentrarmos nos limites do poder regulamentar.

Carlos Ari Sundfeld (2012, p. 156), considerando essa distinção entre primazia de lei e reserva de lei, mas numa análise bastante pertinente ao quadro normativo constitucional brasileiro, admite a existência de pelo menos três fórmulas que determinam o grau de vinculação da Administração frente à lei, a saber: (i) primazia da lei; (ii) imposição de uma genérica dependência de lei para a Administração; e (iii) reservas específicas de lei.

Para Sundfeld (2012, p. 156-157), a primazia da lei estaria fundamentada no que dispõe o art. 37, caput, da Constituição Federal e representaria aquela noção segundo a qual a atividade administrativa não pode contrariar as leis editadas pelo Parlamento. Visto de outro ângulo, a primazia de lei representa a capacidade que possui o Legislativo de, naquelas matérias não sujeitas à reserva legal (geral ou específica), decidir, com certo grau de liberdade, se intervirá de modo direto na ação administrativa, definindo e delimitando a atuação da Administração Pública no grau e intensidade que lhe aprouver, segundo sua política.

Mas como lembra Sundfeld (2012, p. 157):

Se o modelo constitucional se limitasse a isso, a existência da vinculação seria um problema exclusivamente de opção legislativa, pois bastaria que o legislador ficasse inerte para a Administração não ter condicionamentos à sua atuação. Mas o fato - importante para definir a legalidade administrativa na atualidade - é que as Constituições não se contentam com a primazia da lei; vão além, sujeitando a Administração a uma genérica dependência de lei (podese dizer: a uma reserva geral de lei ${ }^{15}$.

Por seu turno, a imposição de uma genérica dependência de lei para a Administração significaria uma reserva geral de lei, de tal sorte que a Administração

15 Tal observação é importantíssima e deixa claro que a configuração do princípio da legalidade, antes de ser uma formulação teórica e universal, é, na verdade, um princípio cuja estrutura e limites depende de modo inafastável do modelo constitucional em particular. 
Pública não possui autonomia para agir (como possuem, por exemplo, os particulares, que podem fazer tudo o que a lei não lhes interdite). Por outros termos, a Administração "não pode agir sem base em lei alguma, não pode editar atos e normas totalmente autônomos" (SUNDFELD, 2012, p. 157).

Haveria três fundamentos constitucionais para essa reserva geral de lei: (i) o disposto no art. 48, caput, da Constituição Federal, segundo o qual cabe ao Congresso Nacional dispor sobre todas as matérias de competência da União, ou seja, o Legislativo possui um amplo espaço material sobre o qual poderá legislar; (ii) a previsão do inciso II do art. $5^{\circ}$ da Constituição Federal, segundo o qual "ninguém será obrigado a fazer ou deixar de fazer alguma coisa senão em virtude de lei" ${ }^{16}$. Com isso, qualquer imposição de obrigações positivas ou negativas aos particulares não poderá ser feita senão por meio de lei formal; (iii) por fim, o terceiro fundamento, segundo Sundfeld (2012, p. 158-159), estaria disperso em diversos dispositivos constitucionais que demandam a edição de lei para a definição e delimitação de competências administrativas, tais como, o art. 37, incisos XIX e XX e o art. 48, inciso XI, todos da Constituição Federal.

Finalmente, as reservas específicas de lei, segundo as quais determinadas matérias deverão ser tratadas por lei, ou seja, por expressa determinação constitucional, certas decisões somente poderão ser tomadas apenas pelo legislador, pelo Parlamento, vinculando de modo bastante intenso a atividade administrativa. Nesses casos, diz Sundfeld (2012, p. 160) que tais reservas específicas criam uma situação de "dependência qualificada da Administração em relação ao legislador".

São exemplos dessa reserva qualificada o disposto no art. 170, parágrafo único, da Constituição Federal, segundo o qual "É assegurado a todos o livre exercício de qualquer atividade econômica, independentemente de autorização de órgãos públicos, salvo nos casos previstos em lei" e, também, o disposto no art. 150, $\S 6^{\circ}$ da Constituição Federal, ao determinar ser vedado à União, aos Estados, ao Distrito Federal e aos Municípios “exigir ou aumentar tributo sem lei que o estabeleça”. Em ambas as hipóteses,

\footnotetext{
${ }^{16}$ Como lembra Marcílio da Silva Ferreira Filho (2014, p. 202), a dicção do art. $5^{\circ}$, inciso II vem sendo repetida pelas Constituições brasileiras desde a Carta de 1891 (art. 72, $\S 1^{\circ}$ ), deixando claro, também, que há um debate doutrinário acerca da exegese desse dispositivo, ou seja, se ele traria uma forma de reserva de lei, ou, ao contrário, uma primazia de lei.
} 
apenas lei formal poderá dispor sobre aquelas matérias, não havendo espaço para o exercício do poder regulamentar.

Dessa sistematização proposta por Sundfeld, segundo os parâmetros de nossa Constituição Federal, podemos concluir que:

(i) a Administração está submetida à lei, não podendo por qualquer modo a contrariar (primazia da lei) - e nesse sentido deve ser interpretado o art. 37, caput, da Constituição Federal;

(ii) por outro lado, qualquer atividade administrativa deve pressupor algum tipo de outorga legal de competência, não sendo admitidos, em geral, atos totalmente autônomos, quer dizer, atos que retirem seu fundamento de validade diretamente da Constituição, sem o intermédio de uma lei formal ${ }^{17}$ - aqui, como se disse, há três fundamentos constitucionais: arts. 48, caput, $5^{\circ}$, II e diversos outros dispositivos que impõem lei para a definição de competências administrativas, tais como os arts. 37, XIX e XX e 48, XI, todos da Constituição Federal. No entanto, aqui, não há qualquer predeterminação de conteúdo obrigatório pela lei, de tal sorte que há uma margem muito maior de liberdade para que o legislador amplie o âmbito de incidência material do poder regulamentar; e

(iii) em determinados casos expressos na Constituição Federal, a vinculação da Administração à lei se dá de modo bastante intenso, demandando do legislador que discipline a matéria com um grau de tal intensidade que ao administrador reste pouquíssima margem de liberdade de decisão. A reserva legal em matéria tributária é um exemplo clássico: nenhum tributo poderá ser criado senão por lei. Assim, a definição dos elementos fundamentais da obrigação jurídica tributária, tais como o fato imponível, os sujeitos ativo e passivo, a base de cálculo e a alíquota, via de regra, salvo as exceções constitucionais, deverão ser definidos por lei. Nesses casos, o campo de incidência do poder regulamentar é mínimo ${ }^{18}$.

${ }^{17}$ Exceto naqueles casos estritos do art. 84, VI, "a" e "b", da Constituição Federal. Nesse sentido, DI PIETRO (2014, p. 94).

${ }^{18}$ Mas ainda assim, não inexistente. Basta ver, por exemplo, que a questão da definição do prazo para o pagamento do tributo (elemento temporal da relação jurídica tributária) é entendido como excluído da reserva legal tributária, consoante decisões do Supremo Tribunal Federal (RE 172.394, por exemplo). O mesmo se diga das obrigações tributárias acessórias, que podem ser criadas (e muitas, de fato o são) por 
É importante destacar que no item (ii) acima, estamos a falar de uma vinculação à lei, mas sem que haja qualquer condicionamento impostos pela Constituição Federal quanto ao conteúdo ou a extensão com que a lei deverá tratar da matéria. Nesses casos, conquanto não se possa prescindir em absoluto da lei, parece evidente que ao legislador compete definir, com relativo grau de liberdade, se pretende regular a matéria de modo exaustivo ou, ao contrário, se partirá apenas da estruturação geral das competências, procedimentos e finalidades a serem alcançadas pela Administração.

Vem a calhar, neste ponto, a lição de Eros Roberto Grau, ao enxergar no art. $5^{\circ}$ inciso II, da Constituição Federal, uma reserva de lei "em termos relativos", mais no sentido de uma "reserva de norma". Isso porque Grau (2014, p. 242) defenda a distinção entre a vinculação da Administração às definições da lei, de um lado, e a vinculação da Administração às definições decorrentes da lei (ou seja, fixadas em virtude dela), de outro. No primeiro caso, haveria uma reserva da lei; no segundo, uma reserva da norma (que pode ser legal, mas também infralegal - regulamentar ou regimental).

Para Grau, o art. $5^{\circ}$, II, da Constituição Federal, não veicula uma reserva geral de lei, mas sim uma primazia da lei para tratar dos assuntos em geral, ao passo que outros dispositivos constitucionais carregariam reservas legais, sem espaço para o exercício da competência regulamentar. $\mathrm{O}$ argumento exposto pelo autor é interessante: se há reservas legais específicas, é porque há espaços em que a lei não alcança, havendo maior liberdade para a administração, do contrário, não haveria razão para tal distinção (GRAU, 2014, p 24-243). O autor separa, assim, a reserva de lei (vinculação da Administração às definições da lei) e reserva de norma (vinculação da Administração às definições decorrentes - isto é, fixadas em virtude dela - da lei).

Esse posicionamento foi acolhido pelo Supremo Tribunal Federal, no bojo do HC 85.060-0/PR (BRASIL, 2009), relatado pelo próprio Grau, quando Ministro daquela Corte. No caso, tratava-se de habeas corpus impetrado contra decisão denegatória de outro writ impetrado perante o Superior Tribunal de Justiça, tendo por um dos fundamentos do pedido a ilegalidade e a inconstitucionalidade da Resolução nº 20/2003 do TRF da $4^{\text {a }}$ Região (que criara a vara especializada em crimes financeiros, onde 
tramitava o processo originário), por ofensa à reserva de lei e por configurar delegação disfarçada e ilegal de competência legislativa.

No seu voto, seguido à unanimidade pela Primeira Turma do STF, o Min. Eros

Grau, incorporando seu posicionamento doutrinário, deixou assentada a distinção entre reserva de lei (reserva absoluta ou em sentido estrito) e reserva de norma (reserva relativa). Do seu voto, podemos destacar o seguinte trecho:

Com efeito, especializar varas e atribuir competências por natureza de feitos não é matéria alcançada pela reserva da lei em sentido estrito, mas apenas pelo princípio da legalidade afirmado no artigo $5^{\circ}$, II da Constituição do Brasil, ou seja, pela reserva da norma. Tome-se o enunciado do preceito: ninguém será obrigado a fazer ou deixar de fazer alguma coisa senão em virtude de lei. Ora, há visível distinção entre as seguintes situações: [i] vinculação às definições da lei; [ii] vinculação às definições decorrentes - isto é, fixadas em virtude dela de lei. No primeiro caso estamos diante da reserva de lei; no segundo, em face da "reserva de norma" [norma que pode ser tanto legal quanto regulamentar; ou regimental]. Na segunda situação, ainda quando as definições em pauta se operem em atos normativos não da espécie legislativa - mas decorrentes de previsão implícita ou explícita em lei - o princípio estará sendo devidamente acatado. No caso, o princípio da legalidade expressa reserva da lei em termos relativos [= reserva da norma], razão pela qual não impede a atribuição, explícita ou implícita, ao Executivo e ao Judiciário, para, no exercício de função normativa, definir obrigações de fazer e não fazer que se imponham aos particulares - e os vincule. Voltando ao artigo $5^{\circ}$, II do texto constitucional, verificamos que, nele, o princípio da legalidade é tomado em termos relativos, o que induz a conclusão de que o devido acatamento lhe estará sendo conferido quando - manifesta, explícita ou implicitamente, atribuição para tanto - ato normativo não legislativo, porém regulamentar ou regimental, definir obrigação de fazer ou não fazer alguma coisa imposta a seus destinatários. Tanto isso é verdadeiro - que o dispositivo constitucional em pauta consagra o princípio da legalidade em termos apenas relativos - que em pelo menos três oportunidades [isto é, no artigo $5^{\circ}$, XXXIX, no artigo 150 , I e no parágrafo único do artigo 170] a Constituição retoma o princípio, então o adotando em termos absolutos (...). Não tivesse o artigo $5^{\circ}$, II consagrado o princípio da legalidade em termos somente relativos e razão não haveria a justificar a sua inserção no bojo da Constituição, em termos então absolutos, nas hipóteses referidas. Dizendo-o de outra forma: se já um princípio de reserva da lei - ou seja, se há matérias que não podem ser reguladas senão pela lei - evidente que das excluídas a essa exigência podem tratar, sobre elas dispondo, o Poder Executivo e o Judiciário, em regulamentos e regimentos (BRASIL, 2009, p. 376377). 
Acolhendo o posicionamento doutrinário de Grau e a exegese realizada pela STF no julgado acima referido, Edilson Pereira Nobre Júnior (2016, p. 25-26), pontua que a existência ou não de uma previsão constitucional específica de reserva legal seria o divisor de águas, de tal sorte que (i) havendo tal previsão, estar-se-ia diante do "monopólio da lei formal"; ao passo que (ii) em não existindo tal previsão, o tema se encontra perante a legalidade tratada pelo inciso II do art. $5^{\circ}$ da Constituição Federal, abrindo-se espaço para a edição de regulamentos pela Administração.

Bockmann Moreira e Heloisa Conrado Caggiano (2013, p. 543), fazendo referência a outra decisão do STF, qual seja, a do HC 91.509-RN (BRASIL, 2010), também relatado pelo Min. Eros Grau, que possui idêntico teor da decisão proferida no acima citado HC 85.060-0/PR (pelo menos no tocante ao princípio da legalidade ao poder regulamentar), sugerem que estaria em curso, no âmbito da nossa Suprema Corte, um processo de mutação constitucional na compreensão das fontes normativas, da competência do Poder Legislativo e da própria concepção do princípio da legalidade.

\section{DOS LIMITES DO PODER REGULAMENTAR (A TÍTULO DE CONCLUSÃO)}

A doutrina clássica do direito administrativo brasileiro, invocando a literalidade dos arts. 5', inciso II, e 84, inciso IV, todos da Constituição Federal, defende que a competência ou poder regulamentar se destina à fiel execução da lei. Exemplo desse pensamento encontramos em Celso Antônio Bandeira de Mello (2010, p. 258), segundo quem, por força do art. 5, II, "só por lei se regulam liberdade e a propriedade; só por lei se impõem obrigações de fazer ou não fazer e só para cumprir dispositivos legais é que o Executivo pode expedir decretos e regulamentos".

De acordo com autor, os regulamentos não podem criar direito e obrigações que não estejam previa e suficientemente caracterizados em lei, isto é, "nela delineados, ao menos pela indicação dos critérios e balizamentos indispensáveis para o reconhecimento de suas composturas básicas" (BANDEIRA DE MELLO, 2010, p. 259). 
Noutra passagem, afirma que "só a lei inova em caráter inicial na ordem jurídica" (BANDEIRA DE MELLO, 1981, p. 96). E mais adiante “existe delegação quando se faculta ao regulamento inovar inicialmente na ordem jurídica. $E$ inovar quer dizer introduzir algo cuja preexistência não se pode conclusivamente deduzir da lei regulamentada" (1981, p. 98).

Nesse sentido, tomando-se a dicção literal e isolada do inciso II do art. $5^{\circ}$, da Constituição Federal, desconsiderando a necessária visão sistêmica, essa doutrina vê no regulamento uma norma que se presta apenas à "fiel execução da lei", tal como expressamente consta do inciso IV do art. 84, da Constituição Federal, nada criando de novo, não gerando norma nova.

Tal visão de poder regulamentar, nas quadras atuais, não se sustenta mais.

Com efeito, o princípio da legalidade não se encerra na dicção literal do inciso II do art. $5^{\circ}$, da Constituição Federal, tal como visto anteriormente. E nem pode tal dispositivo ser analisado de forma isolada, sem considerar o contexto em que se insere o princípio da legalidade no quadro constitucional. Com efeito, e nisto concordamos com Eros Roberto Grau (GRAU, 2014, p. 243), não faz sentido que a Constituição preveja inúmeros casos de reservas específicas de lei, sem considerar, ao mesmo tempo, que nos demais casos em que inexiste tal previsão, o princípio da legalidade opera de modo menos rígido, ensejando maior espaço para a normatização regulamentar.

É certo que as normas oriundas do poder regulamentar não podem contrariar as leis, nem mesmo ultrapassar os seus limites. Isso não se discute. Trata-se, com efeito, de uma decorrência do princípio da legalidade, no sentido de primazia da lei, conforme visto anteriormente. Não obstante, ressalvados os casos de reserva específica de lei, previstos na Constituição, o princípio da legalidade não impede que a lei outorgue competências normativas à Administração (SUNDFELD, 2012, p. 161). De todo modo, essa outorga de competências normativas encontra limites mais ou menos intensos, a depender da densidade normativa da lei outorgante.

Convém salientar, porém, que, a não ser nas hipóteses restritas de leis delegadas, previstas no art. 68 da Constituição Federal, não há espaço no Direito brasileiro para as meras normas de competência ou de delegação, ou seja, de leis que transfiram para a 
Administração a competência de estabelecer de forma ampla e desvinculada de balizas legais o regramento acerca de determinada matéria. Corrobora esse entendimento não só o arcabouço constitucional do princípio da legalidade, conforme acima demonstrado, mas também o que dispõem o art. 49, V, da Constituição Federal e o art. 25, I, do ADCT.

De igual modo, não se coaduna com o nosso sistema constitucional o exercício do poder regulamentar com fundamento normativo direto da Constituição, sem o intermédio de uma lei, a não ser nas hipóteses (restritíssimas, diga-se) do art. 84, VI, "a" e "b", a partir da Emenda Constitucional n ${ }^{\mathrm{o}} 32 / 2001$.

Emerge, desse modo, a grande questão relativa aos limites do poder regulamentar: qual a densidade normativa mínima exigida da lei a fim de que o exercício do poder regulamentar, dada a sua natureza eminentemente infralegal e, pois, subordinada à lei, observe e não transborde os parâmetros de legalidade configurados constitucionalmente.

Com efeito, de acordo com Alexandre Santos de Aragão (2004, p. 57):
A grande questão da matéria do poder regulamentar da Administração Pública não é propriamente a de se determinar a sua extensão deste, mas sim definir qual é a densidade normativa mínima que a sua base legal deve ter para que seja consentânea com o Estado Democrático de Direito e com a natureza subordinada do poder regulamentar.

Como se pode observar, portanto, a grande questão reside na definição do conteúdo mínimo que a lei deva ter a fim de que o exercício do poder normativo pela Administração ocorre em consonância com o princípio da legalidade.

Para Carlos Ari Sundfeld (2012, p.172), “O elemento de divergência, que tem separado defensores e críticos dos ditos regulamentos autorizados, em verdade se resume à existência, ou não, de uma reserva específica de lei quanto à atribuição de deveres $e$ direitos". Segundo ele, talvez haja mais pontos em comum do que divergências entre essas duas visões, na medida em que o debate está centrado, tanto para uns quanto para outros, "na definição do conteúdo mínimo exigível da lei” (2012, p. 174).

Também Francisco de Queiroz Bezerra Cavalcanti (2009, p. 234), nesse diapasão, afirma que "a reserva de densificação mínima da lei é requisito para que uma normatização secundária seja compatível com a Constituição Federal, no sistema jurídico brasileiro". 
A reserva de densificação mínima demanda que a lei estabeleça uma normatização mínima, o que poderá se dar por meio de quadros, standards ou skeleton type, delimitando-se a disciplina básica de determinada matéria, abrindo um espaço maior para atuação do poder regulamentar, não obstante sujeito aos parâmetros de legalidade estabelecidos, ainda que de modo mais aberto e não exaustivo.

De todo modo, como lembra ainda Francisco de Queiroz Bezerra Cavalcanti (2009, p. 232), é fundamental que, "mesmo em se adotando o modelo de quadro, medida, standard, tal tenha densidade suficiente para não se transformar o princípio da legalidade em mero instrumento de fixação de competências", o que, em última análise, implicaria numa delegação de competência legislativa, técnica essa que não encontra guarida no sistema constitucional brasileiro, especialmente em função do que dispõem os arts. 68 e 49, V, da Constituição Federal.

Ademais, não há como se estabelecer um critério geral, válido para todos os casos. Ou seja, não estamos diante de um tema que possa ser resolvido de forma abstrata, tal qual uma fórmula ou método preestabelecido. Como salienta Sundfeld (2012, p. 165), "para enfrentar adequadamente as questões técnicas relevantes, é preciso que a análise se considere cada norma regulamentar em sua individualidade".

Por fim, outro aspecto que merece referência é a corrente afirmação de que o regulamento não pode inovar na ordem jurídica, ou como afirmou Bandeira de Mello (1981, p. 98), “inovar quer dizer introduzir algo cuja preexistência não se pode conclusivamente deduzir da lei regulamentada".

Ora, a noção de inovação não está atrelada, necessariamente, à criação de novos direitos e obrigações, mas sim à ideia de integração de novas normas jurídicas (FERREIRA FILHO, 2016, p. 54). Inovar é agregar algo novo, algo que não existia até então. Pode ser um direito ou uma obrigação, mas pode ser qualquer outro elemento distinto de um direito ou obrigação, ou que lhe constitua apenas um aspecto instrumental, acessório ou complementar.

O caráter inovador é próprio da norma jurídica e não atributo especial de uma das fontes jurídicas que é a lei (GRAU, 2014, p. 235). Evidentemente, a Constituição pode determinar que certas inovações sejam traduzidas por lei apenas, mas isso não afasta o 
caráter inovador das demais normas jurídicas inclusive aquelas veiculadas por fontes de natureza infralegal (FERREIRA FILHO, 2016, p. 211).

Nesse sentido, um regulamento que, a pretexto de dar fiel cumprimento à lei, se limitasse a reproduzir o seu conteúdo, sem acrescentar algo de novo (sem "inovar" na ordem jurídica), seria norma totalmente inútil.

De toda sorte, o quantum de inovação que o regulamento pode carregar não pode ser estabelecido de forma abstrata, senão a partir da análise concreta da matéria a ser tratada por lei com base no texto constitucional (trata-se de reserva geral ou de reserva especial?), do grau de densidade normativa da lei (a lei tratou de forma exaustiva, de forma ampla ou ainda por meio de standards?).

\section{REFERÊNCIAS}

ALBUQUERQUE JR., Raimundo Parente de. Juridicidade contra legem no processo administrativo: limites e possibilidades à luz dos postulados da razoabilidade e da proporcionalidade. Porto Alegre: Livraria do Advogado, 2010.

ARAGÃO, Alexandre Santos de. A concepção pós-positivista do princípio da legalidade. In: Revista de Direito Administrativo, Rio de Janeiro, v. 236, p. 51-64, abr./jun. 2004.

BANDEIRA DE MELLO, Celso Antônio. Ato administrativo e direitos dos administrados. São Paulo: RT, 1981.

. Curso de direito administrativo. São Paulo: Malheiros, 2004.

. Grandes temas do direito administrativo. São Paulo:

Malheiros, 2010.

BRASIL. Supremo Tribunal Federal. Recurso Extraordinário 343.446/SC. Relator Min. Carlos Velloso. Brasília, 04 abr. 2003. Diário de Justiça Eletrônico. Disponível em: $\quad<$ http://redir.stf.jus.br/paginadorpub/paginador.jsp?docTP=AC\&docID=261045>. Acesso em 14 abr. 2017. 
. Habeas Corpus $n^{\mathrm{o}}$ 85.060/PR. Relator Min. Eros Grau.

Brasília, 13 fev. 2009. Diário de Justiça Eletrônico. Disponível em: http://redir.stf.jus.br/paginadorpub/paginador.jsp?docTP=AC\&docID=575869>. Acesso em 14 abr. 2017. . Habeas Corpus no 91.509/RN. Relator Min. Eros Grau.

Brasília, 12 fev. 2010. Diário de Justiça Eletrônico. Disponível em: < http://redir.stf.jus.br/paginadorpub/paginador.jsp?docTP=AC\&docID=607662>. Acesso em 14 abr. 2017.

CARRAZZA, Roque Antônio. Curso de direito constitucional tributário. São Paulo: Malheiros, 2009.

CAVALCANTI, Francisco de Queiroz Bezerra. A reserva de densificação normativa da lei para preservação do princípio da legalidade. In: BRANDÃO, Cláudio; CAVAlCANTI, Francisco; ADEODATO, João Maurício (Coord.). Princípio da legalidade: da dogmática jurídica à teoria do direito. Rio de Janeiro: Forense, 2009, p. 221-234.

CRETELLA JR., José. Curso de direito administrativo. Rio de Janeiro: Forense, 1995.

DI PIETRO, Maria Sylvia Zanella. Direito administrativo. São Paulo: Atlas, 2014.

EISENMANN, Charles. O Direito administrativo e o princípio da legalidade. In: Revista de Direito Administrativo, Rio de Janeiro, v. 56, p. 47-70, jan. 1959.

FERREIRA FILHO, Marcílio da Silva. Poder regulamentar: aspectos controvertidos no contexto da função regulatória. Rio de Janeiro: Lumen Juris, 2016.

GRAU, Eros Roberto. O direito posto e o direito pressuposto. São Paulo: Malheiros, 2014.

HAURIOU, Maurice. Précis de droit administratif et de droit public général: à l'usage des étudiants em licence et en doctorat às-sciences politiques. Paris: Hachette, s/d, fac-símile da edição de 1900.

MAURER, Hartmut. Direito administrativo geral. Barueri: Manole, 2006. 
MEDAUAR, Odete. Direito administrativo moderno. São Paulo: RT, 2012.

MERKL, Adolf. Teoría general del derecho administrativo. México: Coyoacán, 2014. MOREIRA, Egon Bockmann; CAGGIANO, Heloisa Conrado. O poder normativo das agências reguladoras na jurisprudência do STF: mutação constitucional do princípio da legalidade? In: MARQUES NETO, Floriano de Azevedo; ALMEIDA, Fernando Dias Menezes de; NOHARA, Irene Patrícia; MARRARA, Thiago (orgs.). Direito e administração pública: estudos em homenagem a Maria Sylvia Zanella Di Pietro. São Paulo: Atlas, 2013, p. 529-547.

NOBRE JR., Edilson Pereira. Direito administrativo contemporâneo: temas fundamentais. Salvador: JusPodivm, 2016.

OLIVEIRA, Rafael Carvalho Rezende. Princípios de direito administrativo. Rio de Janeiro: Lumen Juris, 2011.

SUNDFELD, Carlos Ari. Direito administrativo para céticos. São Paulo: Malheiros, 2012.

WEIL, Prosper. O direito administrativo. Coimbra: Almedina, 1977. 